\title{
Dream boy: Discuss Kes and Billy Elliot in relation to Raymond Williams’s Categories of Culture*
}

\author{
HE Xin-yu \\ Shanghai Jiao Tong University, Shanghai, China
}

\begin{abstract}
By contrasting the two British films, Kes $^{1}$ and Billy Elliot ${ }^{2}$, which in different historical periods, the paper is a comparative cultural study to films. Aside from the similarities, the differences between the two films precisely show the cultural and social differences in reality. In Raymond Williams' s theory of cultural materialism, culture can be divided into three categories - the dominant, residual and emergent. In relation to this, the 'cultural hybridity' can be shown clearly among the problems (eg. gender, class, sexuality, etc) that the two films involve. Then, I suggest that the relationships between Kes and the 'emergent culture' is an important cultural aspect which Kes exceeds to Billy Elliot.
\end{abstract}

Keywords: Categories of Culture, Social Space, Gender, Class

\section{Introduction}

“He may be a genius for all we know...he’s just a kid!' In Billy Elliot, Billy’s brother, Tony, shouted to his father”. To be precise, Billy Elliot is just a boy, and so does Billy Caspar in Kes. It is rightly that Billy Elliot (2000) is particularly similar to Kes (1969): a similar context for a tender young boy's own special struggle to find a way to realize his creative potential — Billy Caspar trains a hawk and Billy Elliot takes ballet. Both of them come from a single parent family of working-class in coal-fields, and strongly refuse to go down the mine. Both of them look like some feminine and delicate, and each boy has an elder, stronger, crude, and collier brother as an opposite example (at least not a successful model) that they do not hope to follow. What's more, both protagonists get helps from a key local teacher and go to the local library for a book, etc. However, the two similar stories have two different endings_-Billy Caspar’ s hawk is dead, and Billy Elliot achieves his success. In boys, class and gender: from Billy Casper to Billy Elliot, Alan Sinfield investigates the similar patterns and analyses purposeful allusions in depth. He suggests that, despite of the similarities, the latter film is "a placing of

\footnotetext{
* Acknowledgements: This paper was funded by the project “Chinese Contemporary Idea of Tragedy and its Development”, the number of the funding project is 14AZW004.

He Xin-yu is a doctoral candidate in the School of Humanities at Shanghai Jiao Tong University. Her main research fields cover Marxism Aesthetics, and modern tragedy theory.

${ }^{1}$ Kes is a 1969 drama film directed by Ken Loach and produced by Tony Garnett (a team out of the famed BBC Wednesday Play). The film is based on the 1968 novel A Kestrel for a Knave, written by the Barnsley-born author Barry Hines. The film is ranked seventh in the British Film Institute's Top Ten (British) Films and among the top ten in its list of the 50 films you should see by the age of 14 .

${ }^{2}$ Billy Elliot is a 2000 British dance drama film directed by Stephen Daldry. The film is about a boy becoming a professional ballet dancer, set in north-eastern England during the 1984-85 coal miners' strike.
} 
the social realism tradition for the clever viewer" and "offer a specifically different story about class, the state, gender and agency" ${ }^{3}$

When comparing the two films in different periods of British society, I want to put them in relation to Raymond Williams's categories of dominant, residual and emergent cultures. In particularly, we can find both Kes and Billy Elliot are obviously forcing on two important social spaces-families and schools (or educational institutions). They both have deeply significance and relationships with the theory of Marx's 'base and superstructure' (eg. how the dominant state ideologies, especially represented by families and schools, systematically control the adolescents). In Base and Superstructure in Marxist Culture Theory, Raymond Williams debates on the meaning of superstructure emphatically and thinks about culture in a way that 'itself produced'. ${ }^{4}$ First of all, it's an important point to understand the realities of cultural process that the "base" is "a process and not a state”, which is "away from the notion of a fixed economic or technological abstraction". On the basis, "The key question to ask about any notion of totality in cultural theory is this: whether the notion of totality includes the notion of intention (certain social intentions)". Then, it's the "hegemony" which has the advantage to "emphasize the facts of domination". In this case, an important work that Williams has done is connecting cultural interpretation with the dominant, residual or emergent forces. In Williams' s accounts, for instance, speaking of the "dominant culture": there is "a central system of practices, meanings and values, which we can properly call dominant and effective", "which we can call 'alternative to the effective dominant culture". Of course, there is also something "oppositional” that William has said. For example, comparing to modern cities, both Barnsley and Everington are backward, remote, small area, where can hardly integrate into the dominant social system. They have some residual experiences, which make the two protagonists' struggles and talents feeling out of the spaces. In this way, it is necessary to discriminate the dominant, residual and emergent cultural forms in the two films. In Williams' paper, the "residual" always means "some previous social formations that cannot be verified or expressed in the terms of the dominant culture". Corresponding to this, by "emergent" means the new meanings, new values, new experiences, etc, which are continually created. Anyway, the collisions of various cultures have produced "dramatic conflicts" intensely, and the literature criticism, as a way to rethink the dominant culture, is especially significance.

\section{Billy Caspar: Hawk is not a Pet!}

Kes was directed in 1969 by Ken Loach. Loach became a member of the Labor Party from the early 1960s. As a prominent director, he prefers to combine social realism with socialist politics, and his films and TVs always concerns to tell stories about the working class since 1960s and consistently probes the dynamics of the class war. Let's pay attention to a detail in Kes: when Billy Caspar goes into a second-hand bookstore for a book on hawk, there is a poster on the door reads that, "1968, a book about astronomy.” As Loach is a left-wing director, we can hardly not link the film's background to the failure of May, 1968 in France. It seems a little ambiguous by saying that, anyway, 'we have tried, but failed'. However, what on earth is the reason that led to this failure should be the real question to be rethought. In Ken Loach: the politics of film and television, John Hill charts the key shifts from a sincere representation of the realities and struggles of contemporary working class life in Loach's films.

\footnotetext{
3 Alan Sinfield, "boys, class and gender: from Billy Casper to Billy Elliot,” History Workshop Journal 62 (2006): 167.

${ }^{4}$ Raymond Williams, "Base and Superstructure in Marxist Culture Theory," New Left Review (82) (1973): 3-16.
} 
Hill considers that Kes represents "a critical engagement with social injustice and the failure of state institutions”, as well as a restrained style in Loach's aesthetic. ${ }^{5}$ It is vital that Hill highlights Ken Loach as a major presence to reveal the certain transformations in British society over the same period. Meanwhile, another key point is Ken Loach' s social realism always bound up with the more inclusive nature of the postwar settlement. Let's look at Alan Sinfield' s accounts in War stories,

Nevertheless, a distinctive ideology of welfare-capitalism was propagated, and it constituted an unprecedentedly ambitious project of state legitimation. Whereas most social orders have been sustained through religious authority claims and direct physical repression, welfare-capitalism aspires to legitimate itself by claiming that it is what people want. Many of the old symbols remained, but they were democratized (like the royal family) or seemed superficial (like evening dress) ${ }^{6}$

In association with Williams' s cultural materialism, Sinfield points that, "the problem in Kes is cultural: these people expect too little.” With “a distinctive ideology of welfare-capitalism was propagated” in the 1960s' British, in reality, it has became the dominant culture. In the meantime, "this idea was not individuals moving away and becoming middle class, but working-class communities getting a share of the post-war boom.” Under the background of welfare-capitalism, the people in working class have reasons to feel good. However, on the one hand, there are still "many of the old symbols remained"; on the other hand, the people from the old system can hardly adapt to a new system. For example, Kes shows that "plainly these benign changes are not happening in Barnsley” (eg. the school is new but the staffs are mainly horrible men from the old system). As a matter of fact, it suggests a crucial social transformation period.

Then, we can investigate the two categories of spaces in Kes. First, the communities where Billy Caspar lives ( including his school, family and mine), which represent the dominant cultural environment. These dusty, dirty and grey conditions, are the real space Billy lives. As Graham Fuller says, "In Kes, the classes divide on generational rather than economic lines."7 It's especially clear in Billy's school—the upper echelon are the adults or the strong, and the oppressed underclass are the schoolchildren or the weak. Adults continually bully the children because of their advantages in physical strength and labor power. Such as the PE teacher's cruel treatment to Billy, and the football match also means the emphasis of physical ability somehow. In this sense, it is sarcastic that the headmaster appeals for “all kids are the same.” The youngest boy is framed by the others and bullied even by Billy. This contrast means the failure of the whole educational system, which asserts to support working-class youth in British at that period. Ken Jones relates these systems of representation in 1960s to religious and political ideologies, and suggests that education has became "a field in which oppression and hope, destiny and momentary resistance, are active principles." "In Kes, this is problematized, especially in the most sympathetic authority figure.” ${ }^{8}$ By these, I mean that age has became a disadvantage for children at that time, which conducted them by ideologies from both school and family.

\footnotetext{
${ }^{5}$ See Duncan Petrie' s book review (2012) on "Ken Loach: the politics of film and television” (By John Hill, London, British Film Institute-Palgrave Macmillan, 2011).

6 Alan Sinfield, “War stories” from Literature, Politics and Culture in Postwar Britain (London: Blackwell, 1990$): 17$.

7 See Graham Fuller, “Kes: Winged hope”, from The Boke of St. Albans, 1486, and a Harleian manuscript (Used as an epigraph to Barry Hines’ s novel A Kestrel for a Knave, 1968).

${ }^{8}$ Ken Jones, "Representing education 1969-80: notes on Kes and Grange Hill”, History of education, 2001, Vol. 30, No. 2, 141-151.
} 
In fact, Billy Caspar's English teacher Mr. Farthing's understanding to the structural basis is much less clearer than his pupil's. This involves to another side opposites to this, it is also the other kind of space-the field where Billy trains Kes. In Kes, there is quite a long plot shows the process of Billy's falconry, here, hawk is a natural, wild symbolic representation. It doesn't matter that Mr. Farthing is his only spectator, Billy tells Mr. Farthing to be quiet, because he is in command here. This field is a private space only for Billy Caspar, and his falconry performance is holy. In this term, falconry represents some kind of residual culture behind the dominant. Of course, culture collisions between the new and the old are inevitable as well. On the one hand, Kes reflects the complex cultural backgrounds in British in the 1960s. The new systems, such as schools and factories, suggesting the advance of capitalism under the policy of welfare-capitalism in postwar. However, the dominant cultural power always in a dilemma, that deviates from the traditional rural culture and mostly plays an efficient role on national political level. On the other hand, we should notice the fashionable, humanity, and reasonable elements in residual culture. As Williams says, "In the subsequent default of a particular phase of a dominant culture, there is then a reaching back to those meanings and values which were created in real societies in the past, and which still seem to have some significance because they represent areas of human experience, aspiration and achievement, which the dominant culture undervalues or opposes, or even cannot recognise." ${ }^{9}$ In fact, most of Billy's creativity talents come from the experience in his past life (Billy has once raised many small animals) and the knowledge he learns from books. They both can offer him the chances to generate something new.

However, the field is set in the whole Barnsley, and Billy hasn't escaped from the small country throughout the film. Loach explains, "at the time, in the North of England, boys like Billy were needed for unskilled labor.... The world just isn't prepared to take on board the fact that he has talent and imagination, because he's expected to work down the pit all his life, like his brother, and that's if he's lucky.” Without the style of idealism, under the depressive living environment, both Billy and Kes can not master their destinies. As Sinfield exactly points, "Kes refuses the bourgeois solace of having the boy learn from his experience", "By stimulating anger at the thwarted life of Billy Caspar, the film is designed to provoke a demand for a project of social transformation." ${ }^{\prime 10}$ In this sense, Loach's social realism is not the tradition of socialist realism, but an appeal on emergent culture, which pushes the sympathy with the working class into an ethical extension.

\section{Billy Elliot: Ballet is Not Just Poofs!}

As Kes shows us the complexity and diversity of cultures, and offers a tentative explanation on emergent culture; then, Billy Elliot use a dualistic way to performance the dramatic conflicts, and draws close to the dominant culture by an imaginary individual success. Comparing to Billy Caspar's tragic ending, Billy Elliot’ s success certainly encouraging. On account of Billy Elliot' s individual talent, family factors and the background in the 1980's British society, his success in the film also because of the escape to a real cultural issue ( In finally, Billy Elliot achieves his dream in London rather than in Everington).

Billy Elliot was directed by Stephen Daldry in 2000. An important background is that British Prime Minister Margaret Thatcher's government tried to break the coal miners' strike in 1984. As Thatcher came to power in 1979, she rejected the postwar consensus and defeated the National Union of Mine workers for the neoliberal

\footnotetext{
${ }^{9}$ Raymond Williams, “Base and Superstructure in Marxist Culture Theory,” New Left Review (82) (1973): 12.

10 Alan Sinfield, “boys, class and gender: from Billy Casper to Billy Elliot,” History Workshop Journal 62 (2006): 170.
} 
project to succeed. It means an important transfer of "wealth to the wealthy", and resulting in a dramatic increase in inequality. As David Harvey says in Freedom's Just Another Word..., "neoliberalism inevitably uses force to secure the freedom of the free market, and leads to undemocratic cut comes", "Margaret Thatcher made a famous statement about there being no such thing as society. There were only individuals."11 A result is the rich get richer and the poor get poorer, and money has became a key factor for individual victory. Besides, it also influences the dominant cultural aspects in the 1980s' British. David Alderson focuses on the context of neoliberatization in Billy Elliot, and he suggests that this film demonstrates "considerable sympathy for the miners and even a certain kind of affection for their culture." It seems "the function of culture is no longer to humanize, as under the postwar dispensation, but to encourage social aspiration.” Then, "the film's significance is generated not merely by a history that is external to the culture industry but also by institutional transformations within it as these have led to emphasis on individual talent." ${ }^{, 2}$ In the term of culture materialism analysis, this means a key difference from Kes. Despite of Billy Caspar's skill (which mainly from the accumulation of experience and knowledge), Billy Elliot's talent seems more natural, physiological and even genetic ( both his mother and grandmother have artistic genes), which is also an emphasis on individual. To explain this point further, I want to expound from the following two aspects: class and gender.

In The Country and the City, Raymond Williams quotes Trotsky's words, "the history of capitalism was the history of the victory of town over country."13 He takes this as a genuinely historical and political difficulty. In Billy Elliot, We can easily find the confrontations between "city” and "country”. It's an important prerequisite for Billy's success that he leaved Everington for Ballet School in London. Comparing to "country", "city" always represents some modern characteristics, which contains "the capital", "the large town" and "a distinctive form of civilization". It is true that we can always find polices in the corner of the frame or in menacing riot gear ready for direct confrontation with the picketing miners from the film. This can be considered as a symbol— Billy Elliot's escape, largely because the system is already permeable and the class distinction is not the main obstacle for Billy's success. However, the people in working class are always unconscious with their talents. In another word, Billy still needs a person from middle-class to help him. Mrs Wilkinson is a strong, independent woman from middle-class area, who can see Billy's talent and becomes his guardian and sponsor. Every time when Billy wants to abandon, she questions him: don't you want to dance ballet? She has no worries about money, and she can even initiatively offer to pay the Ballet School's tuition fee for Billy ( although Billy's father refuses). As a woman, she dares to argue with Billy's father and brother for Billy's choice to ballet. By these senses I mean, on the contrary (to Kes), age has became an advantage for Billy’s success. The adult miners, such as Jackie and Tony, have no chance to change their jobs and class identifications in reality. Billy is only a kid, which makes him to have individual opportunity to create his future.

Next, let’s think about the miner family. In Kes, Billy Caspar has a dissolutely single mother and a brutal brother, Billy Elliot is obviously more lucky than him. Billy Elliot lost his mother, but he has a grandmother who loves him, and, in fact, Mrs Wilkinson is a substitute mother for Billy. In a boy's growth, father usually plays an

\footnotetext{
11 See David Harvey, “Freedom’s Just Another Word...” (Oxford: Oxford University Press, 2005).

12 David Alderson, "Making Electricity: Narrating Gender, Sexuality and the Neoliberal Transition in Billy Elliot”, Camera Obscura, 75, 2011, 1-27.

13 Raymond Williams, “Cities and Countries” from The Country and the City ( New York: Oxford University Press, 1973 ): 302.
} 
example to be learned or be surpassed. Maybe Billy's father and brother are not excellent enough, however, facing the iniquities in society, they can take actions of resistance (such as they lead the strikes) and attempt to shock the dominant system, their actions should be respected as well. Of course, the means they choose to revolt seems violent, militant and masculine. They can hardly shock the dominant state ideology and even are suppressed by "the repressive state apparatus" at last. There is a difference from the traditional gender cognition - to meet the requirement for walking towards to dominant culture, gender plays an important role for Billy's success. As a boy, Billy lives in an one-dimensionally shaped by a very masculine world since he is born. Louise Althusser suggests that,

That an individual is always-already a subject, even before he is born, is nevertheless the plain reality, accessible to everyone and not a paradox at all....It is clear that this ideological constraint and pre-appointment, and all the rituals of rearing and then education in the family, have some relationship with what Freud studied in the forms of the pre-genitaland genital "stages" of sexuality. ${ }^{14}$

This reminds us of the plot in the beginning of the movie: there is a sharp dividing line of gender between boxing and ballet, which constraints human nature and presents the oppositional to "the effective dominant culture”. As Gary Simmons says in The gloves are off: Billy's pumped : gender and politics class in Billy Elliot, "Billy Elliot explores the preconceptions of what both boys and girls should and shouldn't do. Girls should be passive or do gentle things and boys should be active and be real men." ${ }^{\text {15 }}$ At the end of his paper, Simmons considers Billy Elliot as an important text to understand the cultural theory called "queer theory", which posits the idea that sexual identities are flid, hybrid and indeterminate. In fact, it means the boundary of the female and the male is obscure. Furtherly, Alan Sinfield underlines the developing theme of sexuality from Billy Casper to Billy Elliot, "Kes is dominated by the laddish idea that it is what boys do that counts; Billy Elliot is preoccupied with gender — as it is negotiated by male characters. ${ }^{16}$ It is right that both Mrs Wilkinson' s direct challenge to the male culture and Billy's challenge to the pre-determined life, which mandates boxing and going down the pit, have significant meanings to "bracket feminism" and "recognize the roles of women". Instead of being a boxer or miner, by ballot dancing, the joyful, softer, feminine bodily expression of Billy, transcends class and gender, pointing to a different way to achieve success.

\section{Conclusion}

I suggest that the relationships between Kes and the "emergent culture" is an important cultural aspect which Kes exceeds to Billy Elliot. As Ken Loach says, "In the film (Kes), through the story, you see a whole side to life that the world cannot afford to see, that it can't afford to acknowledge...” and Billy Caspar is "absolutely trapped”. Eventually, Kes is killed by Jud, which also curtails the hope and freedom of Billy. The sympathies and reflections that the film shows are not only to Billy, but also to Billy's mother and Jud. That is, a single mother's degenerate because of her circumstances, as is Jud, whose hatred to his mining job has curdled his spirit. Billy's mother once wonders if Billy would be prospering if he has raised in a different environment, but it isn't the

\footnotetext{
${ }^{14}$ Louis Althusser, excerpts from “Ideology and the Ideological State Apparatuses”, from Essays on Ideology (London: Verso, 1984).

${ }^{15}$ Gary Simmons, “The gloves are off: Billy’s pumped : gender and politics class in Billy Elliot,” Film as Text, 1931-2006, 119-123.

16 Alan Sinfield, “boys, class and gender: from Billy Casper to Billy Elliot,” History Workshop Journal 62 (2006): 169.
} 
realism. For Kes, the bird represents Billy's dream and hope, but Kes is only a creature external to Billy's body, which adds the elements that his skills cannot control. Even if Kes hasn't been killed by Jud, it is still a bird that has its own life, Jud only speeds up its death process artificially, and this is also the sympathetic audiences don't want to see. Anyway, facing to the cultural problems in the country, this point inspires us to think about the social reasons of the film's tragic ending.

Instead of the closed cultural space in Kes, Billy Elliot changes the space that the story happens and takes some kind of nostalgic sympathy and affections to the culture of working class. When Billy Elliot is dancing, he expresses himself with nothing except his own body. In fact, he can’t even articulate the meaning of dance in words until the film's end. About Ballet, Billy says, "I sort of disappear... I feel a change in the body... fie in the body... electricity.” These are just some instinctive senses. When Billy receives the offer of London Ballet school, he seems not very happy. There is no retreat for him from this moment-his dream is not belong to himself, but carrying on the whole dream of his family, whats more, Billy's ballet is no longer as pure as beginning. In fact, the period he studies in London (the film skips over) is also the period Billy's father and brother back to work, which should be a tough and crucial process. Eventually, Billy's powerful leap in the end of the film shows that Billy Elliot has already became a successful dancer. The male's ballet represents a form of cultural, but it is more a kind of individual hero. Billy's dream is achieved out of his hometown, which looks like an illusory symbolical representation to cater the dominant culture. Besides Billy's families and friend, his audiences are the new population in the city, but not the miners. In this sense, Billy Elliot becomes a hero on the state of ballet, but not a real hero in working-class.

Back to Karl Marx's saying, "It is not the consciousness of men that determines their existence, but their social existence that determines their consciousness." ${ }^{17}$ As a theory of cultural materialism, we need to insist on thinking about culture as itself produced, that the literature is not restricted to operating in any one of the sectors, and especially take the specificities of cultural production as determining cultural meaning seriously. In the two movies, an important cultural thing is how to grasp the opportunities and develop sensitivity and creativity in Barnsley or Everington. Loach says, “It wasn't a case of just telling people what to do. I think that's always been very important: as filmmakers, we're not there to order people around; we're there to listen, to absorb, and to try to draw people and serve them. And as far as we could, that's what we did on Kes...” Although Kes is dead, Billy Caspar and his hawk have showed us that it can be done.

As Alan Sinfield quotes Brecht's words on Mother Courage, "it is not the characters, but the audience who should learn.” And “despite Billy Elliot's personal success, it is Billy Caspar who embodies a potential for social change." ${ }^{18}$ When Kes is flying on the field, takes its own "ballet”, infinitely tougher, Billy Caspar feels deep respect for Kes’s grace state. Billy Elliot’s individual success is encouraging and inspiring, and Billy Caspar flies Kes to the future.

\footnotetext{
17 Karl Marx, "Preface to A Critique of Political Economy,” from Karl Marx: Selected Writings (1859).

18 Alan Sinfield, “boys, class and gender: from Billy Casper to Billy Elliot”, History Workshop Journal 62 (2006): 170.
} 